\title{
Bhap Abhiswashan, Jal Neti and Bhastrika Beyond Nasal Cleaning in COVID 19, Era
}

\section{Brajpal Singh Tyagi* Niyati Dhawan and Vishvendra}

Department of ENT, Columbia Asia Hospital Ghaziabad, CEO Harsh ENT Hospital,

Centre for Deafness, ABR Health Care Solutions Limited, India

*Corresponding Author: Brajpal Singh Tyagi, Professor, Head, Department of ENT, Columbia Asia Hospital Ghaziabad, CEO Harsh ENT Hospital, Centre for Deafness, ABR Health Care Solutions Limited, India.
Received: August 06, 2020

Published: August 25, 2020

(C) All rights are reserved by Brajpal Singh Tyagi., et al.

\section{Abstract}

This study had been conducted in Harsh ENT Hospital and Research Center, Ghaziabad on 200 patients. Among these 200 patients, 100 patients had some symptoms of corona illness and therefore, they belonged to Group A. On the contrary, the rest 100 patients were normal patients who were belonged to Group B. When they were treated fairly under Nasal Airway Clearance (Nasal Irrigation), it has been proven that both the groups got better culmination.

In this respect, three major steps had been followed for the immediate recovery of the patients of Group A that were Steam Inhalation, Jal Neti and Bhastrika.

$80 \%$ of patients had recovered very soon with the implementation of these steps and the rest $20 \%$ had been given supportive treatment in order to overcome the symptoms.

Keywords: Bhap Abhiswashan; Jal Neti; Bhastrika; COVID 19; Corona Virus; Steam Inhalation; Ayurveda; Nasal Irrigation; Nasopharyngeal Wash; Nasal Airway Clearance; Nasal Lavage; Nasal Douche

\section{Step 1 - Bhap Abhiswashan (Steam inhalation)}

Among all those above mentioned three major steps, the most convenient and cheapest method is Bhap Abhiswashan. This method is widely regarded as one of the most useful methods that are being practisedat home remedies in order to soothe and open the nasal passages in order to get relief from the symptoms of the common cold.

\section{Method}

Steam Inhalation is very convenient to be implemented at home [1]. At first, the boiled water is poured into a large bowl. Then, the patient has to lean over that results in letting the face directly above the water. Then, the head is to be covered with a towel and the patient must breathe through the nose. In this respect, the pa- tients need not face any difficulties in making the preparation since it takes very few minutes.

\section{Mechanisms of action}

This method simply involves inhalation of water vapours. The mucus and outer fat layer of COVID virus is slackened due to the warm and moist air. This initiative is very much supportive in abating the symptoms of inflamed nasal passages and also it destroys the covering of Corona Virus.

\section{Step 2- Jal Neti (Nasal irrigation)}

Nasal Irrigation is also known as nasal lavage or nasal douche. It is a personal hygiene practice through which the Nasal cavity is being washed for flushing out the mucus and debris from the nose 
in order to bring enhancement of nasal breathing [2]. This practice possesses only minor side effects in spite of being reported as a beneficial practice. Nasal Irrigation is also referred to as the use of the saline nasal spray in order to moisten the mucous membranes. According to the Hindu practice of Indian Ayurveda, Jala Neti means to cleanse the nose with saline water for removing debris and clears the nose.

Method

- Nasal cleansing is performed into three ways namely over a sink, a bowl on a table and in the shower or outside.

- At first, the Neti Pot is to be filled with warm water of a suitable temperature for pouring into the nose. Thensalt is added to this water and after which the water is tasted and spitted in order to be sure of the exact mix and temperature. After a number of attempts, it will be easy to recognize the appropriate correct mixture by taste.

- The nose cone is placed into the right nostril and sealed it inside the nostril with a few twists and slight pressure [3]. When the water is flowing through the nasal passage, the individual should avoid sniffing, swallowing, laughing or talking at the movement of the air.

- Then, the person has to bend forward from the waist in order to make the left nostril as the lowest point of the nose. Then the person needs to keep on breathing from mouth, while the water comes through. After a few minutes, the water will come out from the left nostril. At this moment, breathing must be kept slowly and gently through the mouth. After the water starts flowing, just after 30 seconds for about half a pot to flow right to left.

- Without changing the sides, the person needs to blow out gently from both the nostrils in order to clear water and mucus from the nose [4].

- 2 - 3 above-mentioned steps are to be repeated.

- After continuous repetition of the above mentioned 2 - 3 steps, if mucus blockage is still there, the entire process must be repeated with assiduousness until it clears entirely. After the utilisation of the entire process, the blockage is not over, the person needs to consult an ear, nose surgeon in order to discover whether there is any blockage in the nose.

\section{Step 3 - Bhastrika}

Yoga and Pranayama are very much interrelated with each other and its privileges to the human body are irreplaceable and inevitable. Bhastrika is a significant breathing exercise in yoga and pranayama [5]. Frequently, it is treated as a kriya or 'cleansing action' along with kapalabhati to clear the airways for having the preparation for other pranayama techniques. Bhastrika is the process of rapid inhalation and exhalation that provides a boost to the body, and hence it is aptly called the yogic breath of fire. In the case of exhalation, it is to be done very slowly as well as deeply. The closure of this deep exhalation finishes a perfect round of Bhastrika. It helps in the stimulation of the parasympathetic system and also it increases the power of immunity. Apart from this advantage, this specific pranayama possesses many advantages that are exceedingly beneficial for the wellbeing of the human body. This pranayama enhances the lungs capacity and treats the patients who have been suffering due to the repetitive cough, corona and also allergies. Therefore, this breathing exercise is very much influential and effective for our body.

\section{Method}

In doing this breathing exercise, the individual needs to sit in the posture of Padmasana (Lotus Pose). After that, a deep breath must be taken freely and the lungs are needed to be filled with air. After counting five, the breath is needed to be exhaled. Now, this inhaling and exhaling practice must be continued for 21 times. During this time, a break can be taken for 3 minutes. The repetitive practise plays a key role in increasing the count gradually and also the stamina for is simultaneously be enhanced. Therefore, this method is very much suitable and appropriate for the mental and physical growth of the body [6]. Its contribution to the human body is unspeakable.

\section{Bibliography}

1. Brewster CT., et al. "Steam inhalation and paediatric burns during the COVID-19 pandemic". Lancet 395.10238 (2020): 1690.

2. Principi N and Esposito S. "Nasal irrigation: an imprecisely defined medical procedure". International Journal of Environmental Research and Public Health 14.5 (2019): 516.

3. Qamariah N., et al. "The decrease in bacterialcount in adult chronic rhinosinusitis patients after nasal irrigation therapy 
with $\mathrm{NaCl}$ 0, 9\% Solution". Journal of Physics: Conference Series 1374.1 (2019): 012053).

4. Li CL., et al. "Effectiveness of hypertonic saline nasal irrigation for alleviating allergic rhinitis in children: a systematic review and meta-analysis". Journal of Clinical Medicine 8.1 (2019): 64.

5. Bamne SN. "Effect of Bhastrika pranayama on pulmonary functions of elderly subjects". National Journal of Physiology, Pharmacy and Pharmacology 7.8 (2017): 870.

6. Durai C and Athisayaraj S. "Effect of bhastrika pranayama practices on breath holding time among university hostel students" (2019).

\section{Assets from publication with us}

- Prompt Acknowledgement after receiving the article

- Thorough Double blinded peer review

- Rapid Publication

- Issue of Publication Certificate

- High visibility of your Published work

Website: www.actascientific.com/

Submit Article: www.actascientific.com/submission.php

Email us: editor@actascientific.com

Contact us: +919182824667 